\title{
PEComas: the past, the present and the future
}

\author{
Guido Martignoni - Maurizio Pea • Daniela Reghellin • \\ Giuseppe Zamboni • Franco Bonetti
}

Received: 7 August 2007 / Accepted: 6 September 2007 / Published online: 14 December 2007

(C) Springer-Verlag 2007

\begin{abstract}
The perivascular epithelioid cell (PEC) is a cell type constantly present in a group of tumors called PEComas. PEC expresses myogenic and melanocytic markers, such as HMB45 and actin. Recently, recurrent chromosomal alterations have been demonstrated in PEC. At present, PEComa is a widely accepted entity. In the past 10 years, the use of this term has allowed to report and describe numerous cases permitting to start highlighting the biology of this group of lesions. PEComas are related to the genetic alterations of tuberous sclerosis complex (TSC), an autosomal dominant genetic disease due to losses of TSC1 (9q34) or TSC2 (16p13.3) genes which seem to have a role in the regulation of the Rheb/mTOR/p70S6K pathway. There are some open questions about PEComas regarding its histogenesis, the definition of epithelioid angiomyolipoma and the identification of the histological criteria of malignancy. An innovative therapeutic trial using rapamycin is under way for tumors occurring in TSC such as renal angiomyolipoma and lymphangioleiomyomatosis. Its success could provide the rationale for the use of the same drug in other lesions composed of PECs, especially in the malignant ones.
\end{abstract}

Keywords PEComa PEC A Angiomyolipoma . Lymphangioleiomyomatosis · Sugar tumor . TSC · mTOR · Rapamycin

G. Martignoni $\cdot$ M. Pea $\cdot$ D. Reghellin $\cdot$ G. Zamboni $\cdot$ F. Bonetti Department of Pathology, Università di Verona, Verona, Italy

\section{F. Bonetti $(\bowtie)$}

Anatomia Patologica, Università di Verona,

Strada Le Grazie n. 8,

Verona, Italy

e-mail: franco.bonetti@univr.it

\section{What is the perivascular epithelioid cell?}

The perivascular epithelioid cell (PEC) (Fig. 1) is a cell type constantly present in a group of tumors including angiomyolipoma (AML), clear-cell "sugar" tumor (CCST) of the lung and extrapulmonary sites, lymphangioleiomyomatosis, clear-cell myomelanocytic tumor of the falciform ligament/ligamentum teres and rare clear-cell tumors of other anatomical sites.

It has morphologic, immunohistochemical, ultrastructural and genetic distinctive features such as an epithelioid appearance with a clear to granular cytoplasm, a round to oval, centrally located nucleus and an inconspicuous nucleolus. PEC has mild to any atypia and a typical perivascular location [13]. At present, PEC has not a known normal counterpart.

Immunohistochemically, PEC expresses myogenic and melanocytic markers, such as HMB45, HMSA-1, MelanA/ Mart1, microophtalmia transcription factor (Mitf), actin and, less commonly, desmin $[13,55,126]$. Its immunoreactivity for vimentin is usually incospicuous.

At ultrastructural analysis, PEC contains microfilament bundles with electron-dense condensation, numerous mithocondria and membrane-bound dense granules [11, 118].

It is thought that PEC can modulate its morphology and immunophenotype: given all the characteristics described above (Fig. 2), PEC can show muscular features with a spindle shape and a stronger positivity for actin than for HMB45 or it can have an epithelioid feature with a strong positivity for HMB45 and a mild, if any, reaction for actin (Fig. 3). PEC can also become vacuolized acquiring the feature of an adipocyte. Progesterone receptor positivity has been described in PEC with spindle morphology; this suggests a possible role of progesterone in this morphologic modulation $[13,107]$. 


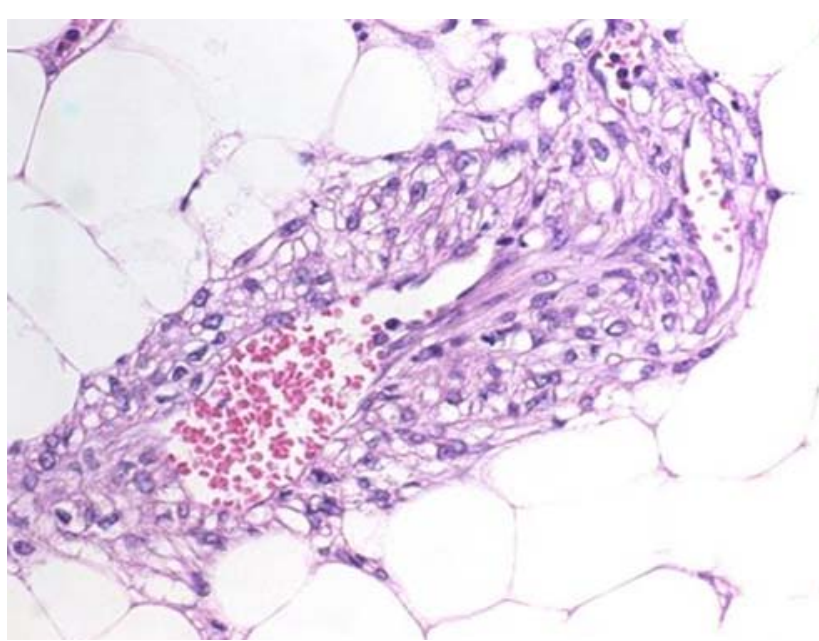

Fig. 1 Renal angiomyolipoma: perivascular epithelioid cells arranged around a blood vessel; H\&E $\times 20$

Recently, recurrent chromosomal alterations have been demonstrated in PEC [87].

\section{What is a PEComa?}

The World Health Organization defines PEComa as "a mesenchymal tumor composed of histologically and immunohistochemically distinctive perivascular epithelioid cells" [37].

At present, this neoplasm is a widely accepted entity. However, some authors cast doubts on the existence of PEComa as a distinctive tumor, particularly as regards the uterine ones that they view as leiomyosarcoma with aberrant expression of HMB45 [102-104]. Although we understand their perplexity, we would like to underline

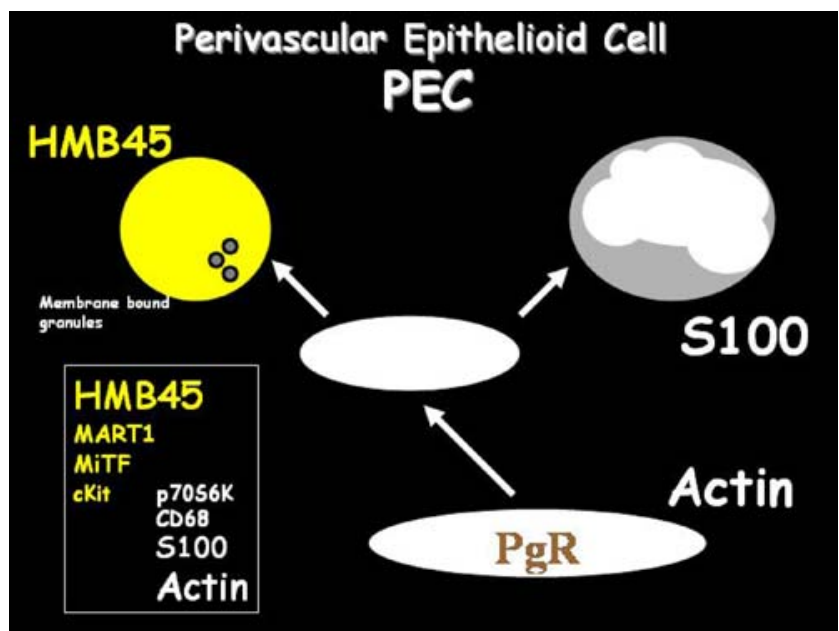

Fig. 2 Diagram demonstrating the modulation of morphology and immunophenotye of PECs

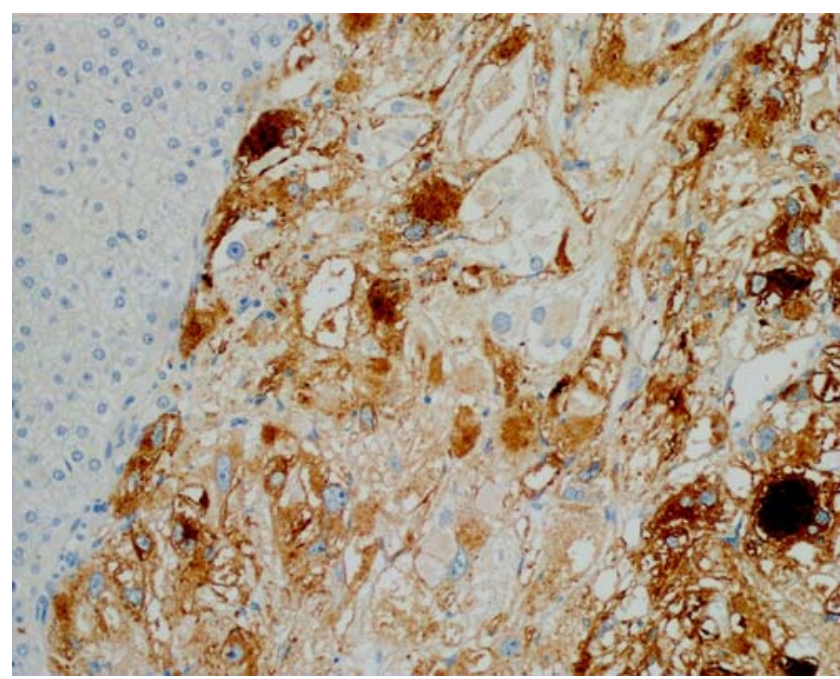

Fig. 3 Hepatic angiomyolipoma: strong granular HMB45 immunoreactivity in perivascular epithelioid cells; HMB45 $\times 20$

some points. First, it has been demonstrated that there are different gene expression profiles among uterine smooth muscle tumors, demonstrating their heterogeneity $[105$, $106,119]$. Second, we think that it is difficult to explain, in uterine smooth muscle neoplasms, both HMB45 and Mitf positivity as an aberrant expression or antibody crossreactivity involving both antigens [81]. Third, we think that the absence of a recognized normal counterpart for PEC is not a sufficient reason to reject the concept of PEComa; in fact, there are other well-accepted soft-tissue neoplasms, such as alveolar soft-part sarcoma and epithelioid sarcoma, that still have not a known normal counterpart.

Some authors have questioned about the use of the term "PEComa". They consider it ambiguous because it is not clear whether this term should be restricted to purely epithelioid tumors as CCST or whether the term should be more broadly applied to include AML and lymphangioleiomyomatosis [80, 111].

We believe that AML, CCST and pulmonary lymphangioleiomyomatosis are composed of PECs in different stages of modulation, and these lesions, together with clear-cell myomelanocytic tumor of the falciform ligament/ligamentum teres, belong to the same family of tumors, the PEComas.

Nevertheless, we think that it is better to continue to name some of them (i.e. AML and pulmonary lymphangioleiomyomatosis) also with their established names which identify their clinical and morphological aspects and are well known by clinicians and pathologists [15].

Moreover, in the past 10 years, the use of the term PEComa has permitted to report and describe numerous cases with the morphological and immunohistochemical features of this tumor permitting to start to understand the biology of this group of lesions. 


\section{PEC and tuberous sclerosis}

PEComas are related to the tuberous sclerosis complex (TSC) or, better, to the genetic alterations of TSC, an autosomal dominant genetic disease due to losses of TSC1 (9q34) or TSC2 (16p13.3) genes [112, 116] and characterized by mental retardation, seizures and cellular proliferations (AMLs, subependymal giant cell tumors, cutaneous angiofibromas, cardiac rabdomyomas, lymphangioleiomyomatosis, pulmonary multifocal micronodular hyperplasia). Similar alterations of the TSC genes have been demonstrated in a significant number of PEComas, both occurring within the TSC and in sporadic cases.

In recent years, great advances have been made in our knowledge of TSC and related lesions. In particular, TSC genes seem to have an important role in the regulation of the Rheb/mTOR/p70S6K pathway [62].

Kenerson et al. [59] have recently demonstrated increased levels of phospho-p70S6K, a marker of mTOR activity, in sporadic AMLs. The associated reduced phospho-AKT expression is consistent with the disruption of $\mathrm{TSC} 1 / 2$ function.

Similar findings were obtained analysing extrarenal PEComas.

\section{PEComa: the past}

PEC was first described in 1943 by Apitz [5] as an "abnormal myoblast" in renal AML, as reported by Masson [77] in his famous book.

The idea of a possible link between AML and other two lesions, CCST and lymphangioleiomyomatosis, came from the fact that the same epithelioid cell was observed in them. Moreover, this cell was HMB45-positive in all three lesions $[9,93,94]$.

Later, ultrastructural examination revealed the presence of premelanosomes both in CCSTs of the lung and in epithelioid clear-cell component of renal and hepatic AMLs $[9,42,43,93,94,118]$.

In addition, the possibility of a relationship between AML and lymphangioleiomyomatosis was suggested by the fact that both occur in TSC [10].

We proposed that CCST should be also included in this syndrome [10], and the first description of this tumor in a patient with TSC confirmed this idea [35].

In 1996, we described the first case of pancreatic CCST and suggested the name PEComa for neoplasms composed of a pure proliferation of PECs [125].

Moreover, the fact that the same clear epithelioid cell composing pulmonary "sugar" tumor was present in AML and was the only component of some small renal microhamartoma (Fig. 4) suggested to us the idea of the existence

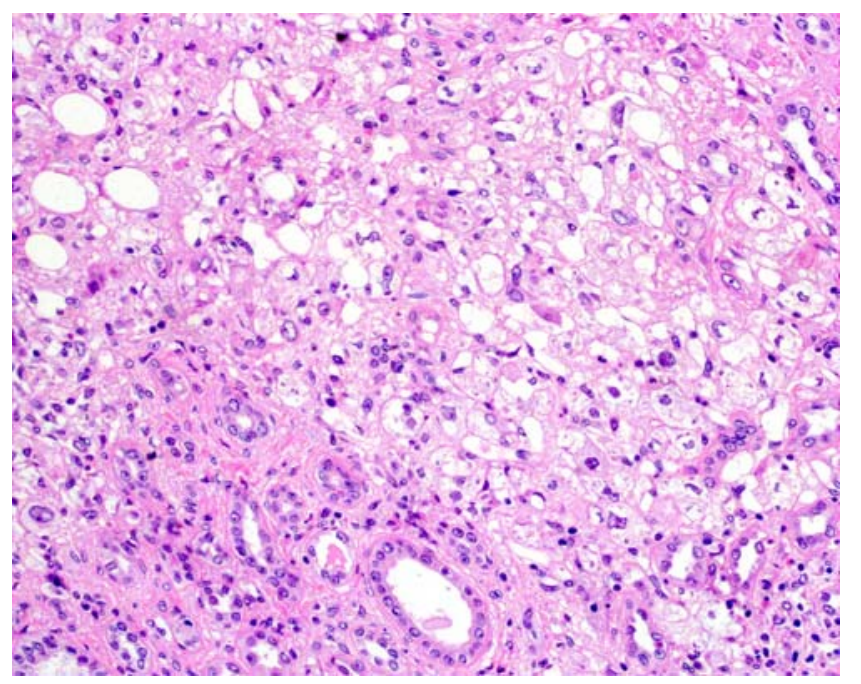

Fig. 4 Renal microhamartoma completely composed of perivascular epithelioid cells; $H \& E \times 20$

of a monotypic epithelioid AML of the kidney. We looked for them, and we found them [96].

\section{PEComa: the present}

PEComas have been described in different organs and are considered ubiquitous tumors.

\section{Kidney}

PEComas of the kidney include classic AML, microscopic AML (so-called microhamartoma), intraglomerular lesions, cystic AML, epithelioid AML, oncocytoma-like AML and lymphangiomyomatosis of the renal sinus.

Classic angiomyolipoma is the most common mesenchymal tumor of the kidney. Being composed of a variable mixture of adipose tissue and spindle and epithelioid smooth muscle cells mixed together with abnormal thickwalled blood vessels, AML is the prototype of the capacity of PEC to modulate its morphology $[29,76]$.

For a long time, AML has been considered a hamartoma rather than a true neoplasm, but, at present, its clonal nature has been demonstrated $[19,57,101]$. In patients with TSC, renal AMLs are found in both sexes, in the third and fourth decades of life, with a female predominance; they are usually asymptomatic, bilateral, small and multifocal. Sporadic AMLs occur in older patients, in the fourth to sixth decades of life, with a female predominance; they are single, unilateral and larger than those associated with TSC [76]. Classic AML contains more than one cell type; if a particular cell type predominates, AML is consequently named (lipoma-like AML or leiomyoma-like AML) [6]. 
Classic AML has a benign outcome. Multifocality and regional lymph node involvement can occur, and this is considered to represent a multifocal growth pattern rather than a metastasis [1, 110]. Three cases of sarcoma developing in sporadic AML have been reported. Similar cases have not been described in TSC patients [22, 32, 73].

Both inherited and sporadic AML frequently demonstrates loss of heterozigosity of chromosome 16p (containing the TSC2 locus). The TSC1 gene occasionally shows loss of heterozigosity $[17,50]$.

Microscopic angiomyolipomas (so-called microhamartomas) They are small nodules often present in a kidney with an AML. They are not homogeneous in appearance and display all the heterogeneous morphologic aspects of AML; microscopic AMLs do not contain thick-walled blood vessels $[13,20]$.

Intraglomerular lesions with similar features of AML have been reported in patients with and without tuberous sclerosis and in the TSC2/PKD1 contiguous gene syndrome, a disease with a deletion disrupting both TSC2 and PKD1 (autosomal dominant polycystic disease gene) [74].

Cystic angiomyolipoma is a recently described variant of AML [25, 33]. It is a solid-cystic lesion that, microscopically, is composed of epithelial cysts lined by cuboidal to hobnail cells, positive for cytokeratin; a compact subepithelial "cambium-like" layer of stromal cells positive for HMB45, Melan-A, CD10, estrogen and progesterone receptors and a solid extracystic component with the morphology of a muscle-predominant (Fig. 5) AML, which is positive for HMB45, estrogen and progesterone receptors, smooth muscle actin and desmin and which is

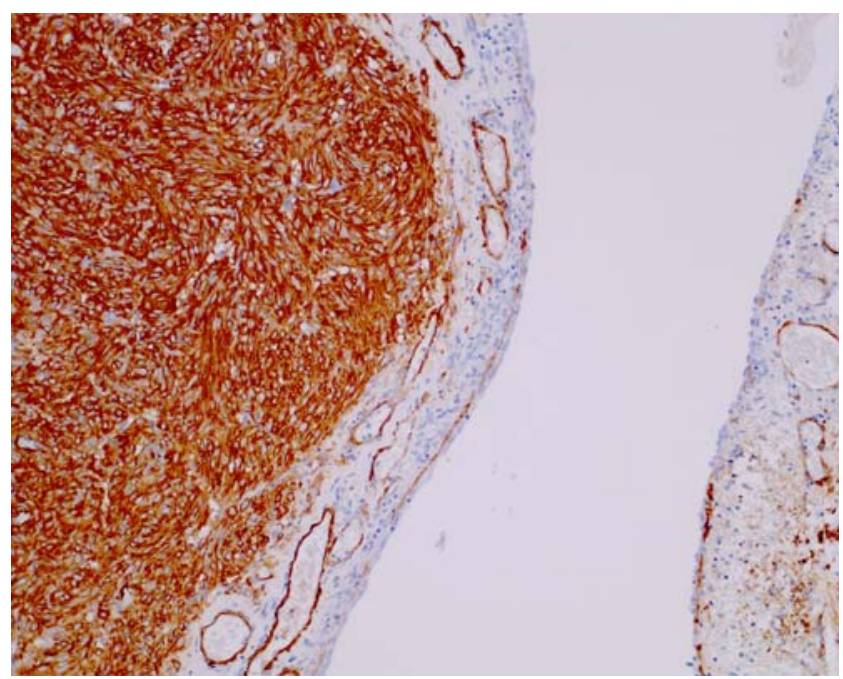

Fig. 5 Cystic angiomyolipoma: strong positivity for actin in the solid extracystic component; SM ACT $\times 10$ associated with irregular blood vessels. Some authors think that the subepithelial "cambium-like" layer is a manifestation of a mullerian differentiation of PEC. If the epithelial cysts represent entrapped renal tubular epithelium [33] or are also related to PEC is unknown.

Only 1 of the 16 cases described to date had a history of TSC [33].

Epithelioid angiomyolipoma is another recently described variant of AML. It is composed of purely epithelioid cells with melanogenesis markers immunoreactivity arranged in sheets. Both adipocytes and abnormal blood vessels are not present. The cytoplasm of the neoplastic cells varies from faintly eosinophilic to clear. Tumor cells can display considerable nuclear atypia, and necrosis can be present. This tumor can recur locally and metastasise causing death. On the basis of histology alone, it is not possible to predict malignant behaviour in these neoplasms, and further data are needed to better define it. However, at the present time, all epithelioid AMLs should be closely followed clinically. Epithelioid AMLs has been described in patient with or without evidence of TSC and in the TSC2/PKD1 contiguous gene syndrome.

Loss of heterozigosity of TSC2 have been reported in some cases of sporadic epithelioid AML [28, 72, 74, 84, 96].

Oncocytoma-like angiomyolipomas are tumors composed of a homogeneous population of HMB45-positive polygonal cells with strongly eosinophilic cytoplasm. They have been described in patients with and without TSC. Recognition of this variant is important because oncocytomas in the same kidney with AMLs have been reported repeatedly and in patients with TSC oncocytomas seem to occur more frequently than in general population [75].

Lymphangiomyomatosis of the renal sinus is a plaque-like mass in the wall of the renal pelvis. All three cases reported to date also had renal AMLs, but in only one of them careful postmortem examination of the lungs revealed pulmonary lymphangiomyomatosis $[74,78]$.

\section{Bladder and prostate}

In 2003, Pan et al. [85, 86] have reported two PEComas of the genitourinary tract in patients without TSC. Both tumors were composed of a variable percentage of epithelioid and spindle cells with clear to granular cytoplasm arranged in nests separated by a vascular stroma. Neoplastic cells were positive for HMB45 but not for epithelial markers, vimentin and S100 protein. The prostatic tumor (Fig. 6) showed a low mitotic activity, coagulative necrosis and a malignant behaviour, whereas the neoplasm 


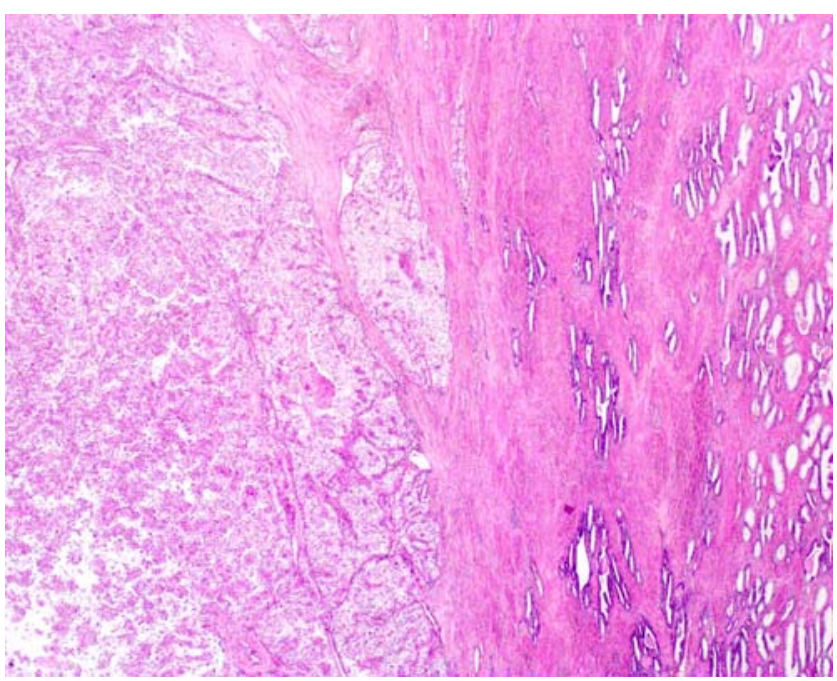

Fig. 6 Prostatic PEComa composed of epithelioid cells with clear cytoplasm arranged in nests; $\mathrm{H} \& \mathrm{E} \times 4$

of the bladder (Fig. 7), lacking these histologic findings, behaved in a benign fashion. Another case of primary PEComa of the bladder has recently been described; also in this case, the patient is well and alive at 48 months after surgery [90].

Finally, Weinreb et al. [120] have recently described a case of PEComa of the urachal cyst composed of pleomorphic cells and containing necrosis and a high mitotic activity. In this case, they also found a peculiar aspect that they named "pecosis": remote from the tumor, there were isolated capillaries surrounded by a single layer of clear cells.

\section{Uterus}

The first case of PEC tumor of the uterus was reported by Pea et al. [95]: it was a polypoid neoplasm involving the

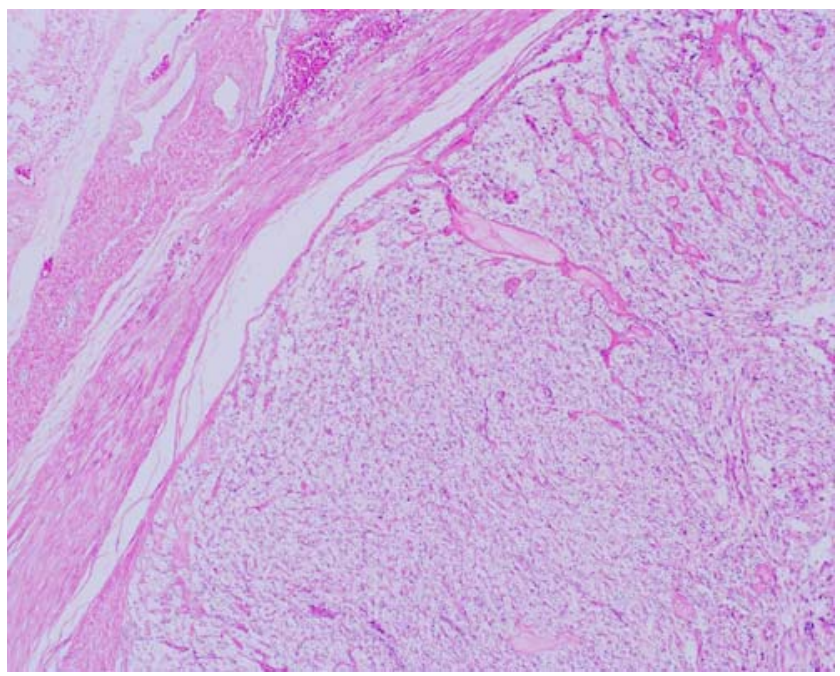

Fig. 7 Bladder PEComa composed of epithelioid cells with clear cytoplasm arranged in nests, $\mathrm{H} \& \mathrm{E} \times 4$

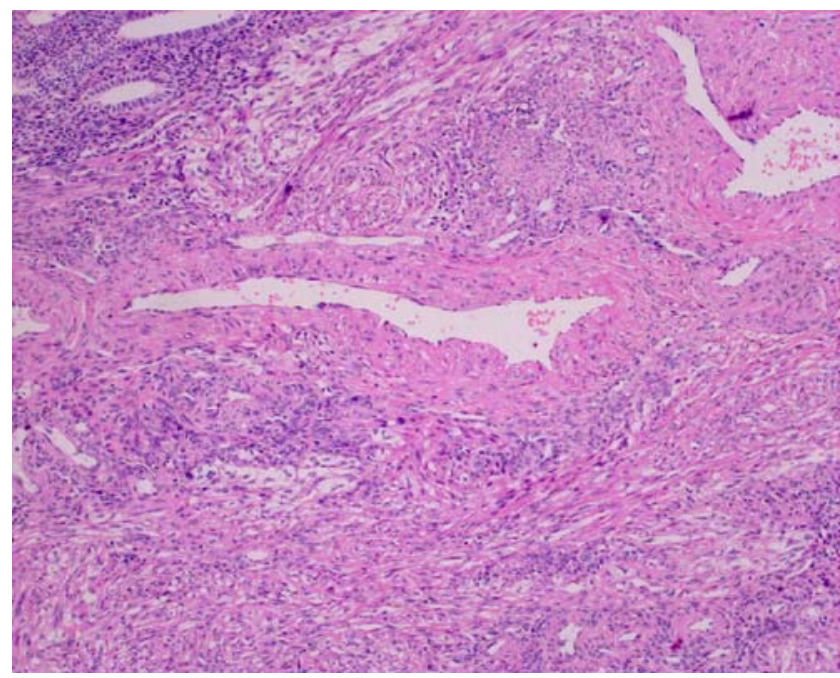

Fig. 8 Uterine PEComa composed of epithelioid cells with a clear cytoplasm and well-defined cell borders; $\mathrm{H} \& \mathrm{E} \times 10$

endometrium, which showed morphological features overlapping those of the CCST of the lung (Fig. 8).

Vang and Kempson [115] described eight cases of uterine PEC tumor ("PEComa"). They distinguished a morphologic spectrum of neoplasms varying from tumors with a tongue-like growth pattern composed of sheets of HMB45-positive clear epithelioid cells, which they called group $\mathrm{A}$, to circumscribed tumors composed of hyalinized stroma and neoplastic cells focally positive for HMB45 and extensively immunoreactive for actin and desmin, which they refer to as group B. In two of these eight cases, pelvic lymph nodes contained lymphangiomyomatosis.

Lesions considered to be uterine involvement of lymphangioleiomyomatosis are usually asymptomatic, and some of them correspond to an incidental finding in patients with TSC.

PEComas of the uterus have usually shown benign behaviour, but 13 tumors, 2 of them associated with TSC, were aggressive [16]. In two of six uterine PEComas described by Folpe et al. [39], patients have metastases and one of six patients died of PEComa.

Fadare et al. [31] described a case of uterine PEComa in a patient with TSC in which there was intra-abdominal "PEComatosis": surgeon found small foci of epithelioid cells in the lamina propria of the small intestine, myometrium and ovarian hilum.

Ovary, vulva and vagina

A tumor with a strong and diffuse HMB45 expression morphologically corresponding to an epithelioid angiomyolipoma has been reported in the ovary [4].

Tazelaar et al. [111] reported a case described as primary extrapulmonary clear-cell "sugar" tumor of the vulva. 
Finally, cases of vaginal PEComa have also been described [39, 83].

\section{Lung}

PEComas of the lung include lymphangioleiomyomatosis and clear-cell "sugar" tumor.

Lymphangioleiomyomatosis (LAM) (Fig. 9) is a rare and progressive disease that affects the lungs of women, usually in premenopausal age; occasionally, it can be extrapulmonary (as described above). It consists of a nodular, often widespread and bilateral interstitial proliferation of HMB45, actin and desmin-positive smooth muscle cells which can vary from small spindle-shaped cells to large epithelioid cells, usually arranged around thin-walled, branching vascular channels; this proliferation is associated with dilated lymphatics and cystic changes $[9,11,18,113]$.

LAM is usually sporadic; patients with TSC are frequently afflicted.

In many cases of LAM, there is a slow progression to pulmonary failure, and the only therapy is lung transplantation. In no-transplanted patient, there is a median survival of $8-10$ years [113].

CCST (Fig. 10) was originally described in the lung [68]. It is a rare and benign neoplasm composed of a uniform population of round-to-polygonal epithelioid cells, with a clear or eosinophilic cytoplasm and well-defined cell borders. Tumor cells are surrounded by prominent and thin-walled vascular channels. CCST has a nested or alveolar appearance. We have also observed adipocytic cells in a few cases of CCST [12]. Tumor cells are positive for HMB45 (Fig. 11) [12, 41, 93].

Pulmonary CCST is rarely associated with TSC [35]; in the vast majority of cases, it is a sporadic lesion.

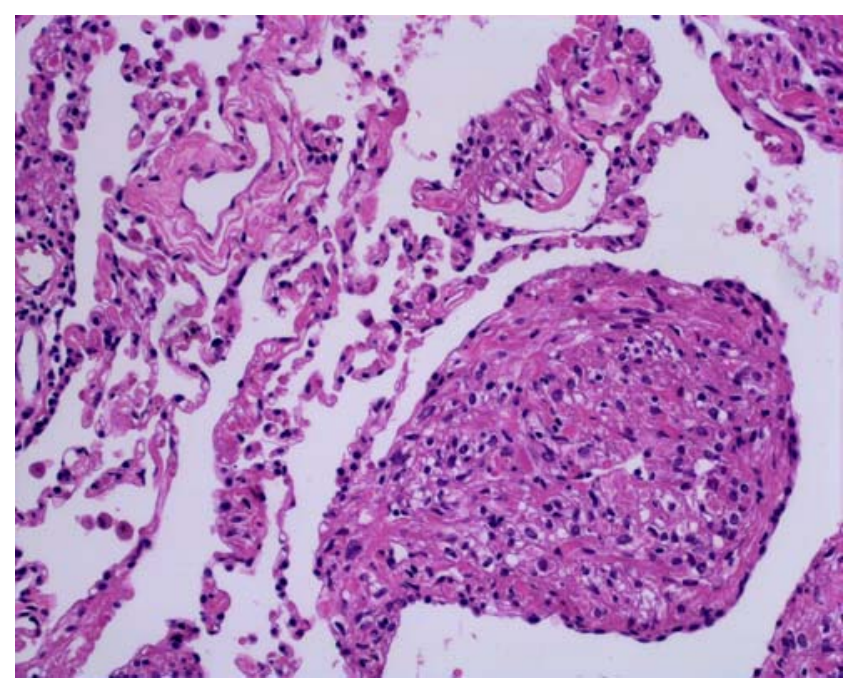

Fig. 9 Pulmonary lymphangioleiomyomatosis composed of epithelioid cells arranged around a vascular channel; H\&E $\times 20$

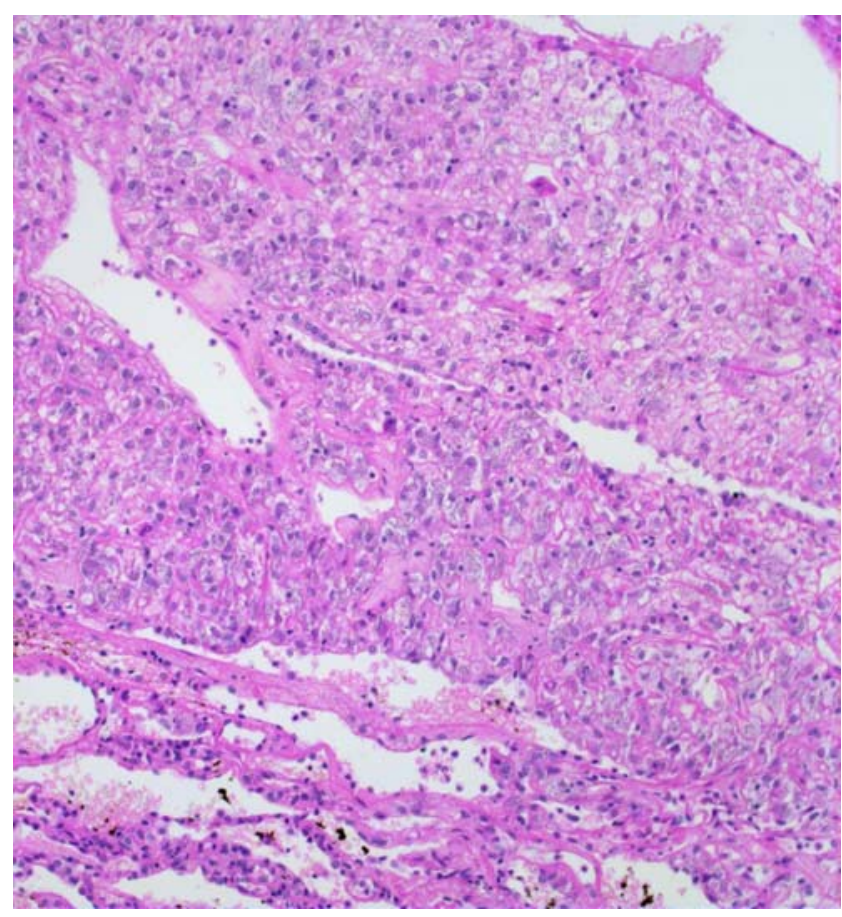

Fig. 10 Pulmonary clear-cell "sugar" tumor composed of epithelioid cells with a clear cytoplasm and well-defined cell borders. A prominent vascular channel is present; $\mathrm{H} \& \mathrm{E} \times 10$

Pancreas

PEComa of the pancreas was reported for the first time in 1996 by Zamboni et al. [125]. It was actually the first time that the very term PEC was introduced (Fig. 12).

The paper reported a tumor with overlapping features of the "benign clear-cell sugar tumor of the lung". This finding was in our opinion consistent with the hypothesis that similar tumors could possibly arise in many if not all locations.

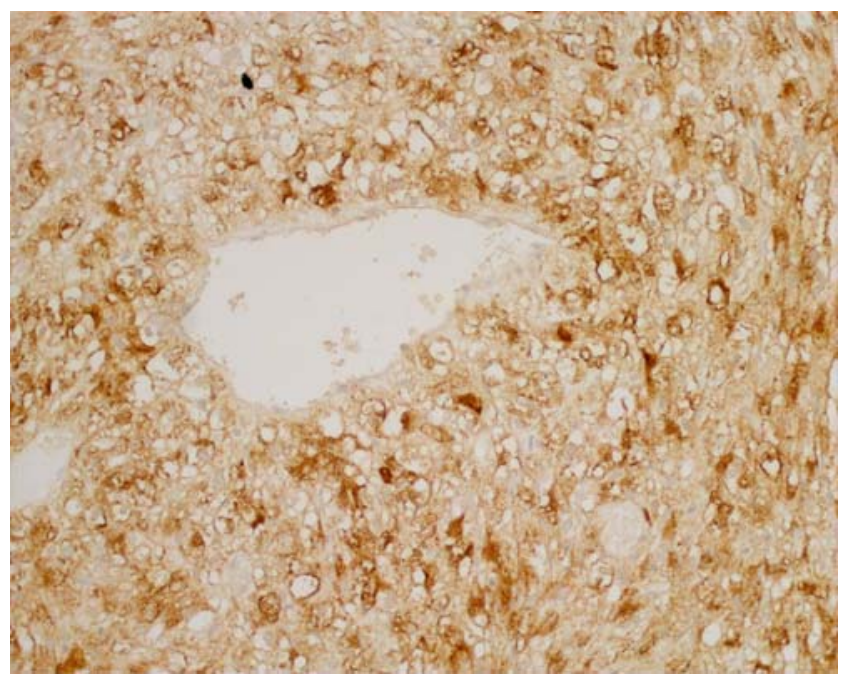

Fig. 11 Pulmonary clear-cell "sugar" tumor: HMB45 immunoreactivity in tumor cells; HMB45 $\times 20$ 


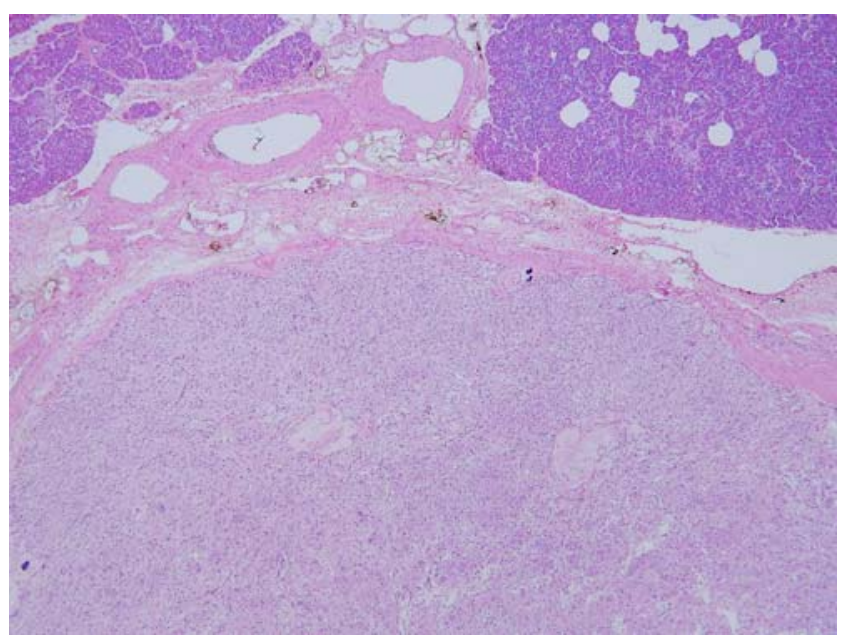

Fig. 12 Pancreatic clear-cell "sugar" tumor: this tumor has overlapping features of the clear-cell "sugar" tumor of the lung: epithelioid cells, with a clear cytoplasm and with a nested appearance; $H \& E \times 4$

Thus the term PEComa was introduced to include all similar lesions arising outside the lung. At the time, we believed this to be a unique case. However, in the following years we have observed other two cases of PEComa of the pancreas with overlapping morphological, phenotypical and clinical features.

Thus, while still a very rare disease of the pancreas, PEComa is not an extraordinary finding in this location.

The clinical aspects of PEComa of the pancreas are interesting because they are discovered incidentally during echography of the abdomen and then investigated usually with cyto-aspiration. The observation of clear epithelioid cells can understandably lead to the wrong diagnosis of clear-cell carcinoma of the pancreas and thus lead to duodenocephalopancreasectomy.

A primary angiomyolipoma of the pancreas has also been described. It was a cephalopancreatic nodule in a nonTSC woman [51].

\section{Liver}

Apart from kidney, liver is the most likely organ involved by angiomyolipoma (Fig. 13), either classic or epithelioid [44, 114, 118]. Frequently, hepatic AML shows a prominent component of large epithelioid cells [114]. There has also been described a case of CCST of the common bile duct [98].

\section{Other sites}

Lymphangioleiomyomatosis has also been reported in extrapulmonary sites including mediastinal and retroperitoneal lymph nodes, soft tissue of the mesentery and the renal sinus, as previously described. Usually, extrapulmonary LAM presents as a localized well-circumscribed mass called "lymphangiomyoma" [78].
Apart from kidney and liver, classic or even epithelioid angiomyolipoma can occur in different visceral and somatic sites as gastrointestinal tract, pelvis [14, 34, 47], nasal cavity [7], soft tissues [49] retroperitoneum [63], bone [53] and orbit [54].

Clear-cell "sugar" tumor has been described in a variety of extrapulmonary sites, apart from uterus and pancreas: skin [26], soft tissues [40], breast [45], skull base [66], gastrointestinal tract $[8,111]$, inter-atrial cardiac septum [111] and oral mucosa [61].

Clear-cell myomelanocytic tumour of the falciform ligament/ligamentum teres (CCMMT) is a PEComa showing predominantly spindled cell morphology.

It has been first described in 2000 by Folpe et al. [36] who presented seven cases of PEComa arising in the abdomen. All patients but one were women ranging from 3 to 21years of age. These neoplasms were composed of spindle cells arranged in fascicles and nests, positive for HMB45 and, in three cases, also for Melan-A, microophtalmia transcription factor (Mitf) and actin. Also in these cases, premelanosomes were ultrastructurally detected. At follow-up, in one patient presumed lung metastasis developed.

CCMMT has also been described in thigh [38] and in the skin [79].

\section{PEComa: the future}

PEComas are a group of ubiquitous neoplasms sharing morphological, immunohistochemical, ultrastructural and genetic distinctive features.

There are some open questions about PEComas: the histogenesis and the normal/physiological counterpart of

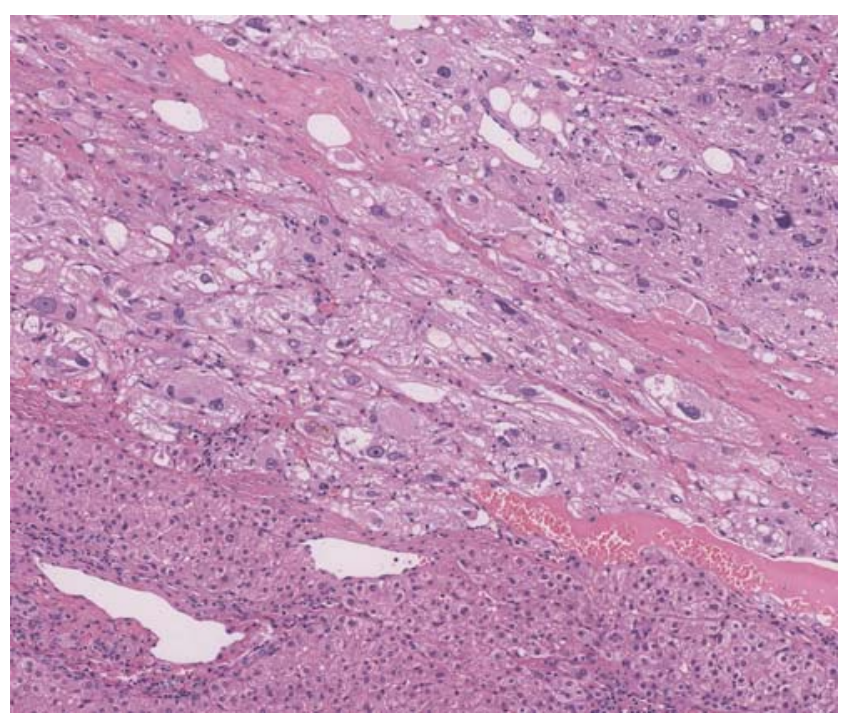

Fig. 13 Hepatic angiomyolipoma: solid component made of large epithelioid cells; $H \& E \times 10$ 


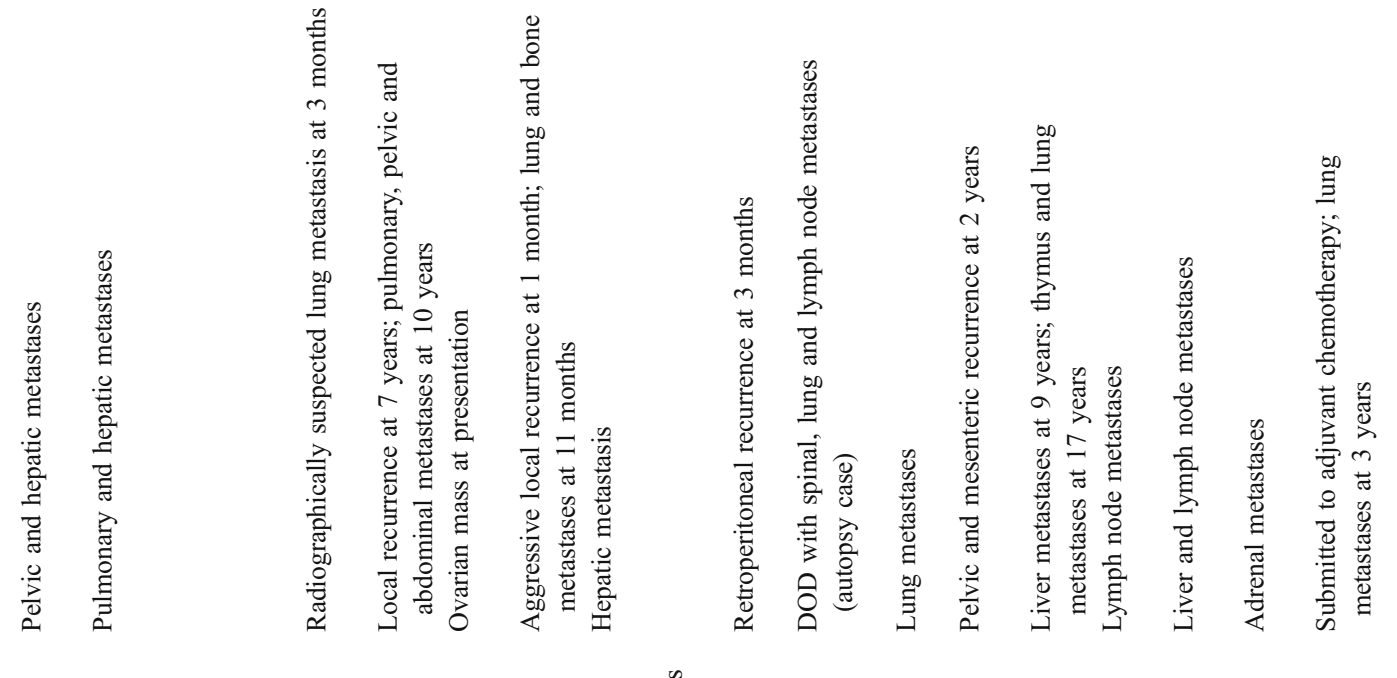

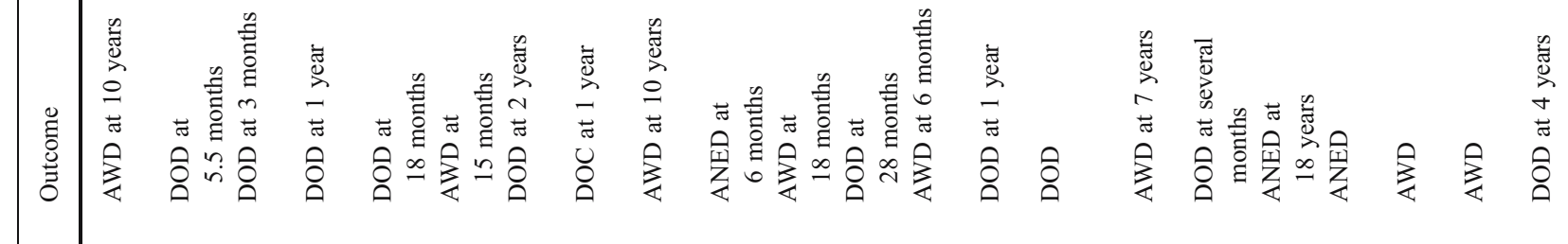

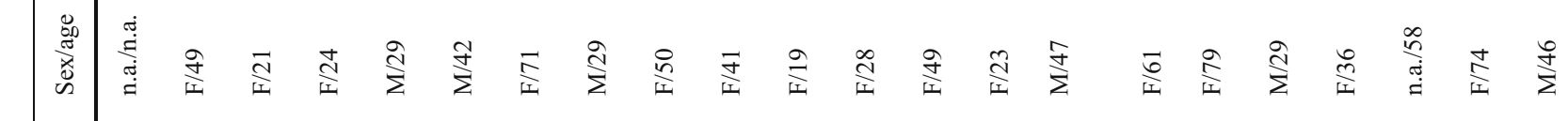

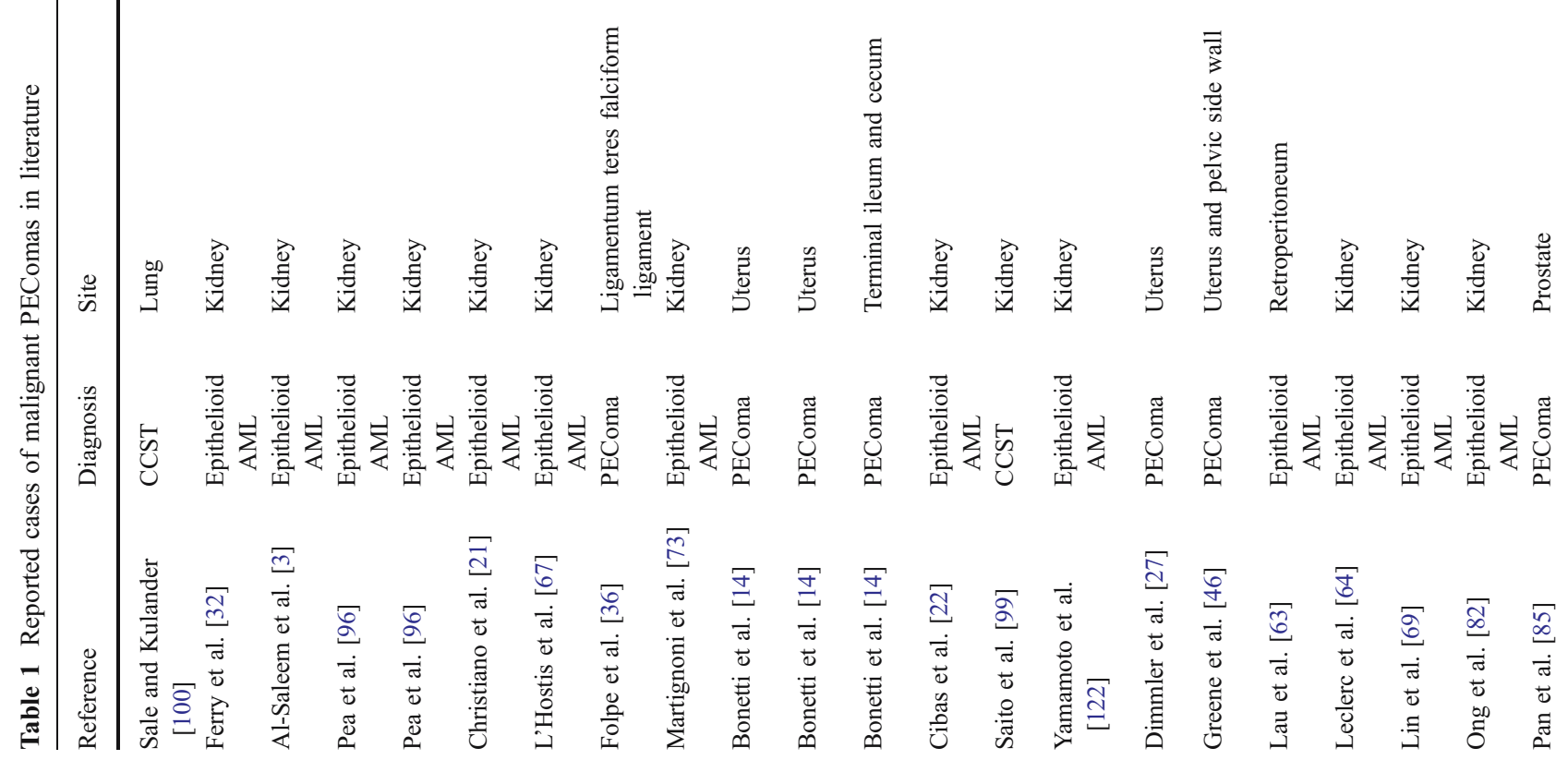




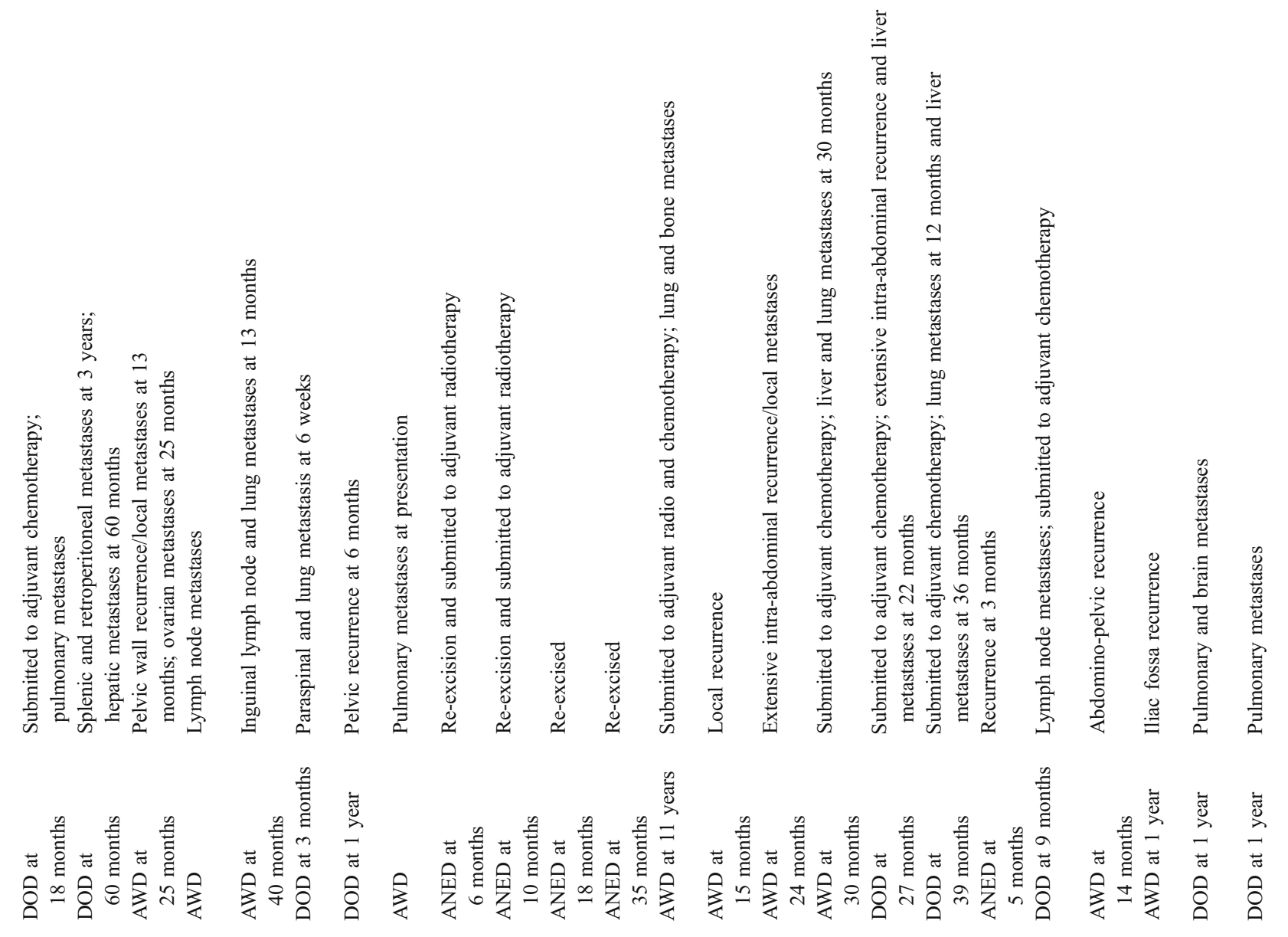

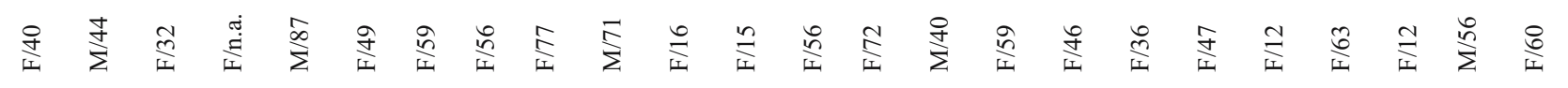

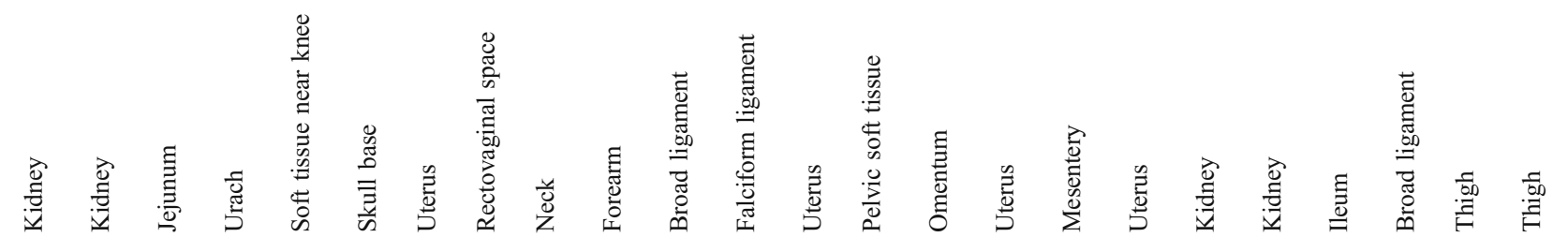

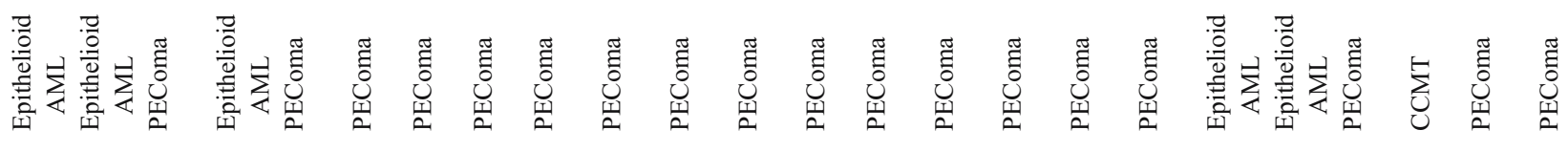

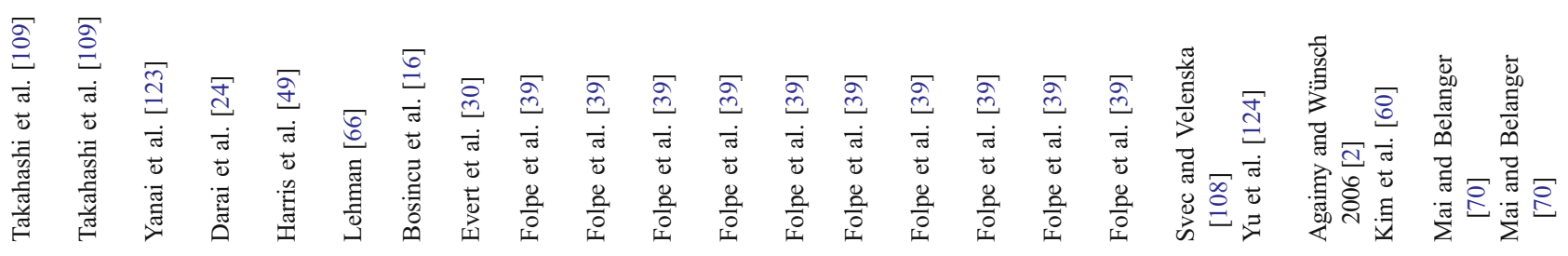


PEC, the definition of epithelioid AML and the identification of the histological criteria of malignancy.

The histogenesis and the normal/physiological counterpart of PEC are unknown, but some hypotheses have been proposed. One hypothesis is that PEC derives from undifferentiated cells of the neural crest that can express dual smooth muscle and melanocytic phenotype; a second hypothesis is that PEC has a myoblastic, smooth muscle origin with a molecular alteration that brings to expression of melanogenesis and melanocytic markers [107]; a third hypothesis is that PEC has a pericytic origin. As regards PEComa's histogenesis, the involvement of TSC pathway in these neoplasms can suggest some possibilities: it has been previously proposed that B-raf activity in cells lacking TSC2 may play a role in cell differentiation [56]. Moreover, TSC pathway regulates negatively Wnt/beta-catenin pathway [71] and beta-catenin regulates transcription of genes involved in cell proliferation and differentiation. Nevertheless, more cases should be analysed to better understand PEC origin and PEComa's histogenesis.

The second issue regarding PEComas is which cases should be classified as epithelioid AML particularly in the kidney and liver, where AML occurs with higher frequency. We defined epithelioid AML as a neoplasm composed of purely epithelioid cells with melanogenesis markers immunoreactivity arranged in sheets, without adipocytes and abnormal blood vessels.

However, in otherwise classic AML, areas of epithelioid cells can be observed, raising the question how much they should be represented to call a tumor "epithelioid angiomyolipoma". The collection of such cases and a consensus meeting could be useful tools to answer to this problem.

Malignant PEComa can be a very aggressive disease leading to multiple metastases and death as expected with a high-grade sarcoma $[3,14,16,32,39,52,66,67,70,85,96$,

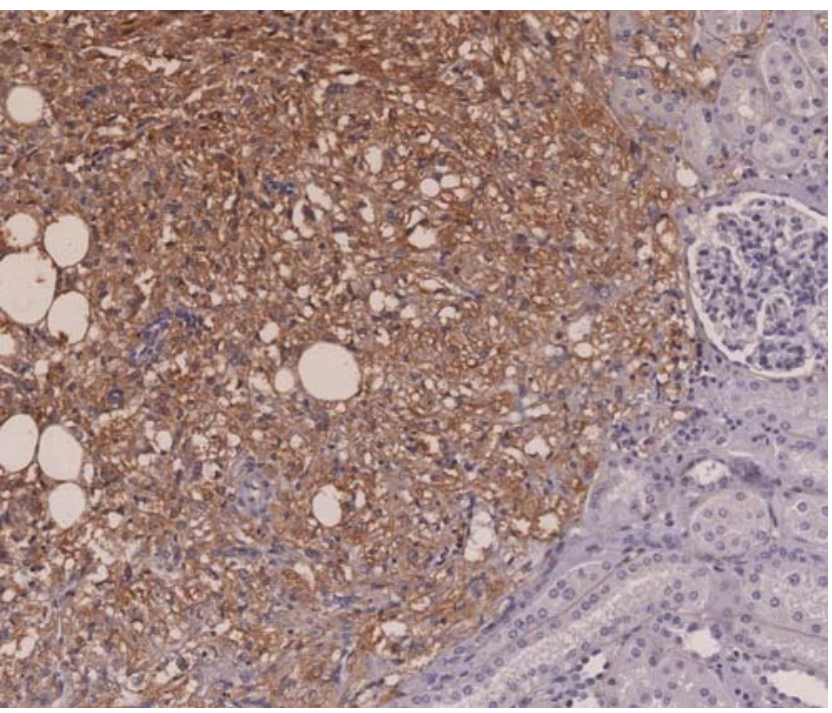

Fig. 14 Hepatic angiomyolipoma: cytoplasmic signal in immunohistochemical reaction for p70S6K; p70S6K $\times 10$ 
99, 109, 121, 124]. A few malignant PEComas metastasised after several years (7-9 years) [27, 73, 89, 100] (Table 1).

Recently, Folpe et al. [39] reported 26 cases of PEComas of soft tissue and gynaecologic origin proposing criteria for the classification of these tumors as "benign", "of uncertain malignant potential" and "malignant". In this study, they observed a significant association between tumor size $>5 \mathrm{~cm}$, infiltrative growth pattern, high nuclear grade, necrosis and mitotic activity $>1 / 50 \mathrm{HPF}$ and subsequent aggressive clinical behaviour of PEComas.

We think that this approach is the best available at the moment. While more cases with long follow-up are needed to verify the effectiveness of this prognostic classification, we believe that all cases of PEComa should be classified according to the criteria proposed by Folpe et al.

Another future challenge regarding PEComas is their management.

Surgery seems to be the only approach for aggressive cases, as chemio- and radiotherapy has not shown significant results. However, this derives from anecdotical cases as no therapeutic trial has so far been implemented. There are obvious difficulties to perform a therapeutic trial mainly due to the rarity of the disease. An international cooperative study is needed to address this problem.

A very different problem is posed by lymphangioleyomyomatosis. In fact, lymphangioleyomyomatosis is composed of a population of cells with no atypia. Mitotic activity is virtually absent or extremely low. In spite of this, the disease usually progresses inexorably towards lung-function impairment.

Recently, Kenerson et al. [59] demonstrated TSC1/2 inactivation and m-TOR hyperactivation in non-TSC AMLs and in extrarenal PEComas using immunohistochemistry and Western blot analysis. In particular, m-TOR hyperactivation can be studied in such lesions using immunohistochemical detection of p70S6K. As we have previously mentioned, p70S6K is a protein kinase activated by $\mathrm{m}$ TOR. Immunohistochemical reaction for p70S6K can stain both p70S6K, which gives a cytoplasmic signal (Fig. 14), and a second isoform of kinase, p85S6K, which is also activated by m-TOR and which gives a nuclear signal.

Rapamycin is a specific inhibitor of m-TOR [23] which is approved by the US Food and Drug Administration for immunosuppression therapy after renal transplant [117], and it has recently been approved also for therapy of renal cell carcinomas and acute myeloid leukemia [88, 97]. Preclinical studies in animal models of TSC have shown significant in vivo response to rapamycin [58, 65].

As regards LAM, an innovative therapeutic trial is under way. Rapamycin seems to block signaling through the Akt cell growth and survival pathway (for up-to-date information, see http://www.thelamfoundation.org).

A similar trial has already shown a positive effect on renal AML, and we can hope to see the same effect on LAM.
If this will be the case, this could provide the rationale for the use of the same drug in other lesions composed of PECs.

Acknowledgements The authors thank Fondazione Cassa di Risparmio di Verona (Unicredit, Cariverona) for financial support.

\section{References}

1. Abdulla M, Bui HX, del Rosario AD, Ross JS (1994) Renal angiomyolipoma. DNA content and immunohistochemical study of classic and multicentric variants. Arch Pathol Lab Med 118:735-739

2. Agaimy A, Wünsch PH (2006) Perivascular epithelioid cell sarcoma (malignant PEComa) of the ileum. Pathol Res Pract 202:37-41

3. Al-Saleem T, Wessner LL, Scheithauer BW, Patterson K, Roach ES, Dreyer SJ, Fujikawa K, Bjornsson J, Bernstein J, Henske EP (1998) Malignant tumors of the kidney, brain, and soft tissues in children and young adults with the tuberous sclerosis complex. Cancer 83:2208-2216

4. Anderson AE, Yang X, Young RH (2002) Epithelioid angiomyolipoma of the ovary: a case report and literature review. Int $\mathrm{J}$ Gynecol Pathol 21:69-73

5. Apitz K (1943) Die Geschwülste und Gewebsmissbildungen der Nierenrinde. II Midteilung. Die mesenchymalen Neubildungen. Virchows Arch 311:306-327

6. Bacchi CE, Bonetti F, Pea M, Martignoni G, Gown AM (1996) HMB-45, a review. Appl Immunohistochem 4:73-85

7. Banerjee SS, Eyden B, Trenholm PW, Sheikh MY, Wakamatsu K, Ancans J, Rosai J (2001) Monotypic angiomyolipoma of the nasal cavity: a heretofore undescribed occurrence. Int J Surg Pathol 9:309-315

8. Birkhaeuser F, Ackermann C, Flueckiger T, Guenin MO, Kern B, Tondelli P, Peterli R (2004) First description of a PEComa (perivascular epithelioid cell tumor) of the colon: report of a case and review of the literature. Dis Colon Rectum 47:1734-1737

9. Bonetti F, Pea M, Martignoni G, Zamboni G, Iuzzolino P (1991) Cellular heterogeneity in lymphangiomyomatosis of the lung. Hum Pathol 22:727-728

10. Bonetti F, Pea M, Martignoni G, Zamboni G (1992) PEC and sugar. Am J Surg Pathol 16:307-308

11. Bonetti F, Chiodera PL, Pea M, Martignoni G, Bosi F, Zamboni G, Mariuzzi GM (1993) Transbronchial biopsy in lymphangiomyomatosis of the lung. HMB45 for diagnosis. Am J Surg Pathol 17:1092-1102

12. Bonetti F, Pea M, Martignoni G, Doglioni C, Zamboni G, Capelli P, Rimondi P, Andrion A (1994) Clear cell ("sugar") tumor of the lung is a lesion strictly related to angiomyolipoma-the concept of a family of lesions characterized by the presence of the perivascular epithelioid cells (PEC). Pathology 26:230-236

13. Bonetti F, Pea M, Martignoni G, Zamboni G, Manfrin E, Colombari R, Mariuzzi GM (1997) The Perivascular Epithelioid Cell and related lesions. Adv Anat Pathol 4:343-358

14. Bonetti F, Martignoni G, Colato C, Manfrin E, Gambacorta M, Faleri M, Bacchi C, Sin VC, Wong NL, Coady M, Chan JK (2001) Abdominopelvic sarcoma of perivascular epithelioid cells. Report of four cases in young women, one with tuberous sclerosis. Mod Pathol 14:563-568

15. Bonetti F, Martignoni G, Pea M (2002) Correspondence re: Bonetti F, Martignoni G, Colato C, Manfrin E, Gambacorta M, Faleri $M$ et al. Abdominopelvic sarcoma of perivascular epithelioid cells. Report of four cases in young women, one with tuberous sclerosis. Mod Pathol 2001;14:563-8. And Tazelaar HD, Batts KP, Srigley JR. Primary extrapulmonary sugar tumor (PEST): a report of four cases. Mod Pathol 2001;14:615-22. Mod Pathol 15:87-90 
16. Bosincu L, Rocca PC, Martignoni G, Nogales FF, Longa L, Maccioni A, Massarelli G (2005) Perivascular epithelioid cell (PEC) tumors of the uterus: a clinicopathologic study of two cases with aggressive features. Mod Pathol 18:1336-1342

17. Carbonara C, Longa L, Grosso E, Mazzucco G, Borrone C, Garrè ML, Brisigotti M, Filippi G, Scabar A, Giannotti A, Falzoni P, Monga G, Garini G, Gabrielli M, Riegler P, Danesino C, Ruggieri M, Magro G, Migone N (1996) Apparent preferential loss of heterozigosity at TSC2 over TSC1 chromosomal region in tuberous sclerosis hamartomas. Genes Chromosomes Cancer 15:18-25

18. Chan JK, Tsang WY, Pau MY, Tang MC, Pang SW, Fletcher CD (1993) Lymphangiomyomatosis and angiomyolipoma: closely related entities characterized by hamartomatous proliferation of HMB-45-positive smooth muscle. Histopathology 22: 445-455

19. Cheng L, Gu J, Eble JN, Bostwick DG, Younger C, MacLennan GT, Abdul-Karim FW, Geary WA, Koch MO, Zhang S, Ulbright TM (2001) Molecular genetic evidence for different clonal origin of components of human renal angiomyolipomas. Am J Surg Pathol 25:1231-1236

20. Chowdhury PR, Tsuda N, Anami M, Hayashi T, Iseki M, Kishikawa F, Kanetake H, Saito Y (1996) A histopathologic and immunohistochemical study of small nodules of renal angiomyolipoma: a comparison of small nodules with angiomyolipoma. Mod Pathol 9:1081-1088

21. Christiano AP, Yang X, Gerber GS (1999) Malignant transformation of renal angiomyolipoma. J Urol 161:1900-1901

22. Cibas ES, Goss GA, Kulke MH, Demetri GD, Fletcher CD (2001) Malignant epithelioid angiomyolipoma ('sarcoma ex angiomyolipoma') of the kidney: a case report and review of the literature. Am J Surg Pathol 25:121-126

23. Cohen E (2006) m-TOR inhibitors. Clin Adv Hematol Oncol 4:38-39

24. Darai E, Bazot M, Barranger E, Detchev R, Cortez A (2004) Epithelioid angiomyolipoma of the uterus: a case report. J Reprod Med 49:578-581

25. Davis CJ, Barton JH, Sesterhenn IA (2006) Cystic angiomyolipoma of the kidney: a clinicopathologic description of 11 cases. Mod Pathol 19:669-674

26. de Saint Aubain Somerhausen N, Gomez Galdon M, Bouffioux B, Courtin C, Theunis A, Vogeleer MN, Myant N (2005) Clear cell 'sugar' tumor (PEComa) of the skin: a case report. J Cutan Pathol 32:441-444

27. Dimmler A, Seitz G, Hohenberger W, Kirchner T, Faller G (2003) Late pulmonary metastasis in uterine PEComa. J Clin Pathol 56:627-628

28. Eble JN, Amin MB, Young RH (1997) Epithelioid angiomyolipoma of the kidney: a report of five cases with a prominent and diagnostically confusing epithelioid smooth muscle component. Am J Surg Pathol 21:1123-1130

29. Eble JN (1998) Angiomyolipoma of kidney. Semin Diagn Pathol $15: 21-40$

30. Evert M, Wardelmann E, Nestler G, Schultz HU, Roessner A, Röcken C (2005) Abdominopelvic perivascular epithelioid cell sarcoma (malignant PEComa) mimicking gastrointestinal stromal tumour of the rectum. Histopathology 46:115-117

31. Fadare O, Parkash V, Yilmaz Y, Mariappan MR, Ma L, Hileeto D, Qumsiyeh MB, Hui P (2004) Perivascular epithelioid cell tumor (PEComa) of the uterine cervix associated with intraabdominal 'PEComatosis': a clinicopathological study with comparative genomic hybridization analysis. World J Surg Oncol 2:35

32. Ferry JA, Malt RA, Young RH (1991) Renal angiomyolipoma with sarcomatous transformation and pulmonary metastases. Am J Surg Pathol 15:1083-1088
33. Fine SW, Reuter VE, Epstein JI, Argani P (2006) Angiomyolipoma with epithelial cysts (AMLEC). A distinctive cystic variant of angiomyolipoma. Am J Surg Pathol 30:593-599

34. Fink D, Marsden DE, Edwards L, Camaris C, Hacker NF (2004) Malignant perivascular epithelioid cell tumor (PEComa) arising in the broad ligament. Int J Gynecol Cancer 14:10361039

35. Flieder DB, Travis WD (1997) Clear cell 'sugar' tumor of the lung: association with lymphangioleiomyomatosis and multifocal micronodular pneumocyte hyperplasia in a patient with tuberous sclerosis. Am J Surg Pathol 21:1242-1247

36. Folpe AL, Goodman ZD, Ishak KG, Paulino AF, Taboada EM, Meehan SA, Weiss SW (2000) Clear cell myomelanocytic tumor of the falciform ligament/ligamentum teres: a novel member of the perivascular epithelioid clear cell family of tumors with a predilection for children and young adults. Am J Surg Pathol 24:1239-1246

37. Folpe AL (2002) Neoplasms with perivascular epithelioid cell differentiation (PEComas). In: Fletcher CDM, Unni KK, Epstein J, Mertens F (eds) Pathology and genetics of tumours of soft tissue and bone. Series: WHO Classification of tumours. IARC Press, Lyon, pp 221-222

38. Folpe AL, McKenney JK, Li Z, Smith SJ, Weiss SW (2002) Clear cell myelomelanocytic tumor of the thigh: report of a unique case. Am J Surg Pathol 26:809-812

39. Folpe AL, Mentzel T, Lehr HA, Fisher C, Balzer BL, Weiss SW (2005) Perivascular epitheliod cell neoplasms of soft tissue and gynecologic origin: a clinicopathologic study of 26 cases and review of the literature. Am J Surg Pathol 29:1558-1575

40. Fukunaga M (2004) Perivascular epithelioid cell tumor (PEComa) of soft tissue. Case report with ultrastructural study. APMIS 112:98-104

41. Gaffey MJ, Mills SE, Askin FB, Ross GW, Sale GE, Kulander BG, Visscher DW, Yousem SA, Colby TV (1990) Clear cell tumor of th e lung. A clinicopathologic, immunohistochemical, and ultrastructural study of eight cases. Am J Surg Pathol $14: 248-259$

42. Gaffey MJ, Mills SE, Zarbo RJ, Weiss LM, Gown AM (1991) Clear cell tumor of the lung. Immunohistochemical and ultrastructural evidence of melanogenesis. Am J Surg Pathol $15: 644-653$

43. Gal AA, Koss MN, Hochholzer L, Chejfec G (1991) An immunohistochemical study of benign clear cell ('sugar') tumor of the lung. Arch Pathol Lab Med 115:1034-1038

44. Goodman ZD, Ishak KG (1984) Angiomyolipomas of the liver. Am J Surg Pathol 8:745-750

45. Govender D, Sabaratnam RM, Essa AS (2002) Clear cell 'sugar' tumor of the breast: another extrapulmonary site and review of the literature. Am J Surg Pathol 26:670-675

46. Greene LA, Mount SL, Schned AR, Cooper K (2003) Recurrent perivascular epithelioid cell tumor of the uterus (PEComa): an immunohistochemical study and review of the literature. Gynecol Oncol 90:677-681

47. Gronchi A, Diment J, Colecchia M, Fiore M, Santinami M (2004) Atypical pleomorphic angiomyolipoma localized to the pelvis: a case report and review of the literature. Histopathology 44:292-295

48. Gupta C, Malani AK, Gupta V, Singh J, Ammar H (2007) Metastatic retroperitoneal epithelioid angiomyolipoma. J Clin Pathol 60:428-431

49. Harris GC, McCulloch TA, Perks G, Fisher C (2004) Malignant perivascular epithelioid cell tumor ('PEComa') of soft tissue: a unique case. Am J Surg Pathol 28:1655-1658

50. Henske EP, Neumann HP, Scheithauer BW, Herbst EW, Short MP, Kwiatkowski DJ (1995) Loss of heterozigosity in the tuberous sclerosis (TSC2) region of chromosome band 16 p13 
occurs in sporadic as well as TSC-associated renal angiomyolipomas. Genes Chromosomes Cancer 13:295-298

51. Heywood G, Smyrk TC, Donohue JH (2004) Primary angiomyolipoma of the pancreas. Pancreas 28:443-445

52. Huang KH, Huang CY, Chung SD, Pu YS, Shun CT, Chen J (2007) Malignant epithelioid angiomyolipoma of the kidney. J Formos Med Assoc 106(2 Suppl):S51-54

53. Insabato L, De Rosa G, Terracciano LM, Fazioli F, Di Santo F, Rosai J (2002) Primary monotypic epithelioid angiomyolipoma of bone. Histopathology 40:286-290

54. Iyengar P, Deangelis DD, Greenberg M, Taylor G (2005) Perivascular epithelioid cell tumor of the orbit: a case report and review of the literature. Pediatr Dev Pathol 8:98-104

55. Jungbluth AA, Busam KJ, Gerald WL et al (1998) A103: an anti-melan-a monoclonal antibody for the detection of malignant melanoma in paraffin-embedded tissues. Am J Surg Pathol 22:595-602

56. Karbowniczek M, Henske EP (2005) The role of tuberin in cellular differentiation: are B-Raf and MAPK involved? Ann N Y Acad Sci 1059:168-173

57. Kattar MM, Grignon DJ, Eble JN, Hurley PM, Lewis PE, Sakr WE, Cher ML (1999) Chromosomal analysis of renal angiomyolipoma by comparative genomic hybridization: evidence for clonal origin. Hum Pathol 30:295-299

58. Kenerson H, Dundon TA, Yeung RS (2005) Effects of rapamycin in the Eker rat model of tuberous sclerosis complex. Pediatr Res 57:67-75

59. Kenerson H, Folpe AL, Takayama TK, Yeung RS (2007) Activation of the mTOR pathway in sporadic angiomyolipomas and other epithelioid cell neoplasms. Hum Pathol 38:1361-1371

60. Kim HJ, Lim SJ, Choi H, Park K (2006) Malignant clear-cell myomelanocytic tumor of broad ligament-a case report. Virchows Arch 448:867-870

61. Koutlas IG, Pambuccian SE, Jessurun J, Manivel JC, Gopalakrishnan R (2005) Perivascular epithelioid cell tumor of the oral mucosa. Arch Pathol Lab Med 129:690-693

62. Kwiatkowski DJ (2003) Tuberous sclerosis: from tubers to mTOR. Ann Hum Genet 67:87-96

63. Lau SK, Marchevsky AM, McKenna RJ, Luthringer DJ (2003) Malignant monotypic epithelioid angiomyolipoma of the retroperitoneum. Int J Surg Pathol 11:223-228

64. Leclerc JC, Marchal F, Stines J, Régent D (2003) L'angiomyolipome rénal épithélioide: tumeur bénigne ou maligne? J Radiol $84: 851-854$

65. Lee L, Sudentas P, Donohue B, Asrican K, Worku A, Walker V, Sun Y, Schmidt K, Albert MS, El-Hashemite N, Lader AS, Onda H, Zhang H, Kwiatkowski DJ, Debora SL (2005) Efficacy of rapamycin analog (CCI-779) and IFN-gamma in tuberous sclerosis mouse models. Genes Chromosomes Cancer 42:213-227

66. Lehman NL (2004) Malignant PEComa of the skull base. Am J Surg Pathol 28:1230-1232

67. L'Hostis BA, Diminiere C, Ferriere JM, Coindre JM (1999) Renal angiomyolipoma: a clinicopathologic, immunohistochemical, and follow-up study of 46 cases. Am J Surg Pathol 23:1011-1020

68. Liebow AA, Castleman B (1971) Benign clear cell ('sugar') tumors of the lung. Yale J Biol Med 43:213-222

69. Lin WC, Wang JH, Wei CJ, Pan CC, Chang CY (2003) Malignant renal epithelioid angiomyolipoma with aggressive behaviour and distant metastases. J Chin Med Assoc 66:303-306

70. Mai KT, Belanger EC (2006) Perivascular epithelioid cell tumour (PEComa) of the soft tissue. Pathology 38:415-420

71. Mak BC, Takemaru K, Kenerson HL, Moon RT, Yeung RS (2003) The tuberin-hamartin complex negatively regulates betacatenin signalling activity. J Biol Chem 278:5947-5951
72. Martignoni G, Pea M, Bonetti F, Zamboni G, Carbonara C, Longa L, Zancanaro C, Maran M, Brisigotti M, Mariuzzi GM (1998) Carcinomalike monotypic epithelioid angiomyolipoma in patients without evidence of tuberous sclerosis: a clinicopathologic and genetic study. Am J Surg Pathol 22:663-672

73. Martignoni G, Pea M, Rigaud G, Manfrin E, Colato C, Zamboni G, Scarpa A, Tardanico R, Roncalli M, Bonetti F (2000) Renal angiomyolipoma with epithelioid sarcomatous transformation and metastases: demonstration of the same genetic defects in the primary and metastatic lesions. Am J Surg Pathol 24:889-894

74. Martignoni G, Bonetti F, Pea M, Tardanico R, Brunelli M, Eble JN (2002) Renal disease in adults with TSC2/PKD1 contiguous gene syndrome. Am J Surg Pathol 26:198-205

75. Martignoni G, Pea M, Bonetti F, Brunelli M, Eble JN (2002) Oncocytoma-like angiomyolipoma. A clinicopathologic and immunohistochemical study of 2 cases. Arch Pathol Lab Med 126:610-612

76. Martignoni G, Amin M (2004) Angiomyolipoma. In: Eble JN, Sauter G, Epstein J, Sesterhenn I (eds) Pathology and genetics of tumours of the urinary system and male genital organs series: WHO classification of tumours. IARC Press, Lyon, pp 65-67

77. Masson P (1970) Origin of fibromyolipomas. In: Human tumors. Histology, diagnosis, and technique. Detroit: Wayne State University Press 735-736

78. Matsui K, Tatsuguchi A, Valencia J, Yu Z, Bechtle J, Beasley MB, Avila N, Travis WD, Moss J, Ferrans VJ (2000) Extrapulmonary lymphangioleiomyomatosis (LAM): clinicopathologic features in 22 cases. Hum Pathol 31:1242-1248

79. Mentzel T, Reisshauer S, Rütten A, Hantschke M, Soares de Almeida LM, Kutzner H (2005) Cutaneous clear cell myomelanocytic tumour: a new member of the growing family of perivascular epithelioid cell tumours (PEComas). Clinicopathological and immunohistochemical analysis of seven cases. Histopathology 46:498-504

80. Nuciforo PG, O'Hara CD (2002) Correspondence re: Bonetti F, Martignoni G, Colato C, Manfrin E, Gambacorta M, Faleri M et al. Abdominopelvic sarcoma of perivascular epithelioid cells. Report of four cases in young women, one with tuberous sclerosis. Mod Pathol 2001;14:563-8. And Tazelaar HD, Batts KP, Srigley JR. Primary extrapulmonary sugar tumor (PEST): a report of four cases. Mod Pathol 2001;14:615-22. Mod Pathol 15:87-90

81. Oliva E, Wang WL, Branton P, Logani S, Zannoni GF, Linkov I, Asher M, Soslow RA (2006) Expression of melanocytic ("PEComa") markers in smooth muscle tumors of the uterus: an immunohistochemical analysis of 86 cases. (Abstract) 95th USCAP Annual Meeting, Atlanta, Georgia

82. Ong A, Pinto P, Kim F, Kavoussi L (2003) Recurrent renal epithelioid angiomyolipoma. Urology 61:1035iii-1035v

83. Ong LY, Hwang WS, Wong A, Chan MY, Chui CH (2007) Perivascular epithelioid cell tumour of the vagina in an 8 year old girl. J Pediatr Surg 42:564-566

84. Pan CC, Chung MY (2006) Loss of heterozygosity of TSC2 and TSC1 gene in perivascular epithelioid cell tumor (PEComa). (Abstract) 95th USCAP Annual Meeting, Atlanta, Georgia

85. Pan CC, Yang AH, Chiang H (2003) Malignant perivascular epithelioid cell tumor involving the prostate. Arch Patol Lab Med 127:E96-E98

86. Pan CC, Yu IT, Yang AH, Chiang H (2003) Clear cell myomelanocytic tumor of the urinary bladder. Am J Surg Pathol 27:689-692

87. Pan CC, Jong YJ, Chai CY, Huang SH, Chen YJ (2006) Comparative genomic hybridization study of perivascular epithelioid cell tumor. Molecular genetic evidence of perivascular epithelioid cell tumor as a distinctive neoplasm. Hum Pathol 37:606-612

88. Pantuck AJ, Thomas G, Belldegrun AS, Figlin RA (2006) Mammalian target of rapamycin inhibitors in renal cell carcinoma: current status and future applications. Semin Oncol 33:607-613 
89. Parfitt JR, Bella AJ, Izawa JI, Wehrli BM (2006) Malignant neoplasm of perivascular epithelioid cells of the liver. Arch Pathol Lab Med 130:1219-1222

90. Parfitt JR, Bella AJ, Wehrli BM, Izawa JI (2006) Primary PEComa of the bladder treated with primary excision and adjuvant interferon-alpha immunotherapy: a case report. BMC Urol 6:20

91. Parfitt JR, Keith JL, Megyesi JF, Ang LC (2006) Metastatic PEComa to the brain. Acta Neuropathol (Berl) 112:349-351

92. Park HK, Zhang S, Wong MK, Kim HL (2007) Clinical presentation of epithelioid angiomyolipoma. Int J Urol 14:21-25

93. Pea M, Bonetti F, Zamboni G, Martignoni G, Fiore-Donati L, Doglioni C (1991) Clear cell tumor and angiomyolipoma. Am J Surg Pathol 15:199-202

94. Pea M, Bonetti F, Zamboni G, Martignoni G, Riva M, Colombari R, Mombello A, Bonzanini M, Scarpa A, Ghimenton C et al (1991) Melanocyte-marker HMB-45 is regularly expressed in angiomyolipoma of the kidney. Pathology 23:185-188

95. Pea M, Martignoni G, Zamboni G, Bonetti F (1996) Perivascular epithelioid cell. Am J Surg Pathol 20:1149-1153

96. Pea M, Bonetti F, Martignoni G, Henske EP, Manfrin E, Colato C, Bernstein J (1998) Apparent renal cell carcinomas in tuberous sclerosis are heterogeneous: the identification of malignant epithelioid angiomyolipoma. Am J Surg Pathol 22: 180-187

97. Récher C, Dos Santos C, Demur C, Payrastre B (2005) mTOR, a new therapeutic target in acute myeloid leukemia. Cell Cycle 4:1540-1549

98. Sadeghi S, Krigman H, Maluf H (2004) Perivascular epithelioid clear cell tumor of the common bile duct. Am J Surg Pathol 28:1107-1110

99. Saito K, Fujii Y, Kasahara I, Kobayashi N, Kasuga T, Kihara K (2002) Malignant clear cell "sugar" tumor of the kidney: clear cell variant of epithelioid angiomyolipoma. J Urol 168:2533-2534

100. Sale GE, Kulander BG (1988) "Benign" clear-cell tumor (sugar tumor) of the lung with hepatic metastases ten years after resection of pulmonary primary tumor. Arch Pathol Lab Med 112:1177-1178

101. Sepp T, Yates JR, Green AJ (1996) Loss of heterozigosity in tuberous sclerosis hamartomas. J Med Genet 33:962-964

102. Silva EG, Deavers MT, Bodurka DC, Malpica A (2004) Uterine epithelioid leiomyosarcomas with clear cells. Reactivity with HMB-45 and the concept of PEComa. Am J Surg Pathol 28:244249

103. Silva EG, Bodurka DC, Scouros MA, Ayala A (2005) A uterine leiomyosarcoma that became positive for HMB45 in the metastasis. Ann Diagn Pathol 9:43-45

104. Simpson KW, Albores-Saavedra J (2007) HMB-45 reactivity in conventional uterine leiomyosarcomas. Am J Surg Pathol 31:95-98

105. Skubitz KM, Skubitz APN (2003) Differential gene expression in uterine leiomyoma. J Lab Clin Med 141:297-308

106. Skubitz KM, Skubitz APN (2003) Differential gene expression in leiomyosarcoma. Cancer 98-1029-1038

107. Stone $\mathrm{CH}$, Lee MW, Amin MB, Yaziji H, Gown AM, Ro JY, Tètu B, Paraf F, Zarbo RJ (2001) Renal angiomyolipoma: further immunophenotypic characterization of an expanding morphologic spectrum. Arch Pathol Lab Med 125:751-758

108. Svec A, Velenska Z (2005) Renal epithelioid angiomyolipoma-a close mimic of renal cell carcinoma. Report of a case and review of the literature. Pathol Res Pract 200:851-856

109. Takahashi N, Kitahara R, Hishimoto Y, Ohguro A, Hashimoto Y, Suzuki T (2003) Malignant transformation of renal angiomyolipoma. Int J Urol 10:271-273

110. Tallarigo C, Baldassarre R, Bianchi G, Comunale L, Olivo G, Pea M, Bonetti F, Martignoni G, Zamboni G, Mobilio G (1992) Diagnostic and therapeutic problems in multicentric renal angiomyolipoma. J Urol 148:1880-1884

111. Tazelaar HD, Batts KP, Srigley JR (2001) Primary extrapulmonary sugar tumor (PEST): a report of four cases. Mod Pathol 14:615-622
112. The European Chromosome 16 Tuberous Sclerosis Consortium (1993) Identification and characterization of the tuberous sclerosis gene on chromosome 16. Cell 75:1305-1315

113. Travis WD, Colby TV, Koss MN, Rosado-de-Christenson ML, Muller NL, King Jr TE (2002) Atlas of nontumor pathology: nonneoplastic disorders of the lower respiratory tract, First Series, Fascicle 2. American Registry of Pathology, Washington D.C

114. Tsui WM, Colombari R, Portmann BC, Bonetti F, Thung SN, Ferrell LD, Nakanuma Y, Snover DC, Bioulac-Sage P, Dhillon AP (1999) Hepatic angiomyolipoma: a clinicopathologic study of 30 cases and delineation of unusual morphologic variants. Am J Surg Pathol 23:34-48

115. Vang R, Kempson RL (2002) Perivascular epithelioid cell tumor ('PEComa') of the uterus: a subset of HMB-45-positive epithelioid mesenchymal neoplasms with an uncertain relationship to pure smooth muscle tumors. Am J Surg Pathol 26:1-13

116. van Slegtenhorst M, de Hoogt R, Hermans C, Nellist M, Janssen B, Verhoef S, Lindhout D, van den Ouweland A, Halley D, Young J, Burley M, Jeremiah S, Woodward K, Nahmias J, Fox M, Ekong R, Osborne J, Wolfe J, Povey S, Snell RG, Cheadle JP, Jones AC, Tachataki M, Ravine D, Sampson JR, Reeve MP, Richardson P, Wilmer F, Munro C, Hawkins TL, Sepp T, Ali JB, Ward S, Green AJ, Yates JR, Kwiatkowska J, Henske EP, Short MP, Haines JH, Jozwiak S, Kwiatkowski DJ (1997) Identification of the tuberous sclerosis gene TSC1 on chromosome 9q34. Science 277:805-808

117. Webster AC, Lee VW, Chapman JR, Craig JC (2006) Target of rapamycin inhibitors (sirolimus and everolimus) for primary immunosuppression of kidney transplant recipients: a systematic review and meta-analysis of randomized trials. Transplantation $81: 1234-1248$

118. Weeks DA, Malott RL, Arnesen M, Zuppan C, Aitken D, Mierau G (1991) Hepatic angiomyolipoma with striated granules and positivity with melanoma - specific antibody (HMB-45): a report of two cases. Ultrastruct Pathol 15:563-571

119. Wei J, Chiriboga L, Mizuguchi M, Yee H, Mittal K (2005) Expression profile of tuberin and some potential tumorigenic factors in 60 patients with uterine leiomyomata. Mod Pathol 18:179-188

120. Weinreb I, Howarth D, Latta E, Ghazarian D, Chetty R (2007) Perivascular epithelioid cell neoplasms (PEComas): four malignant cases expanding the histopathological spectrum and description of a unique finding. Virchows Archiv 450:463-470

121. Yamamoto H, Oda Y, Takashi Y, Oiwa T, Kobayashi C, Tamia S, Kawaguchi K, Hino O, Tsuneyoshi M (2006) Malignant perivascular epithelioid cell tumor of the colon: report of a case with molecular analysis. Pathol Int 56:46-50

122. Yamamoto T, Ito K, Suzuki K, Yamanaka H, Ebihara K, Sasaki A (2002) Rapidly progressive malignant epithelioid angiomyolipoma of the kidney. J Urol 168:190-191

123. Yanai H, Matsuura H, Sonobe $H$, Shiozaki S, Kawabata K (2003) Perivascular epithelioid cell tumor of the jejunum. Pathol Res Pract 199:47-50

124. Yu W, Fraser RB, Gaskin DA, Fernandez CV, Wright, JR, Jr (2005) C-Kit-positive metastatic malignant pigmented clear-cell epithelioid tumor arising from the kidney in a child without tuberous sclerosis. Ann Diagn Pathol 9:330-334

125. Zamboni G, Pea M, Martignoni G, Zancanaro C, Faccioli G, Gilioli E, Pederzoli P, Bonetti F (1996) Clear cell "sugar" tumor of the pancreas. A novel member of the family of lesions characterized by the presence of perivascular epithelioid cells. Am J Surg Pathol 20:722-730

126. Zavala-Pompa A, Folpe AL, Jimenez RE, Lim SD, Cohen C, Eble JN, Amin MB (2001) Immunohistochemical study of microophtalmia transcription factor and tyrosinase in angiomyolipoma of the kidney, renal cell carcinoma, and renal and retroperitoneal sarcomas: comparative evaluation with traditional diagnostic markers. Am J Surg Pathol 25:65-70 